\title{
Evaluation of Efficiency and Biodegradability of Lubricant Oil Treated by Sequencing Batch Reactor (SBR)
}

\author{
Boonchai Wichitsathian and Watcharapol Wonglertarak
}

\begin{abstract}
Oily wastewater is one of the most concerned pollution sources due to its consisting of toxic substances such as phenols, petroleum hydrocarbons, and polyaromatic hydrocarbons. Those substances are also inhibitory to plant and animal growth as well as mutagenic and carcinogenic to human being. Such kind of wastewater is mainly originated from crude oil production, oil refinery, petrochemical industry, lubricant and car washing. The purpose of this study was to investigate the effect of lubricant oil concentration normally used in a gas station on the performance of SBR. The experiment was performed by varying concentration of lubricant oil from 50 to500 $\mathrm{mg} / \mathrm{L}$ in SBR with HRT $24 \mathrm{hrs}$. The results indicated that the effective removal of COD was in the range of $84-87 \%$. The oil removal efficiency was found to be in the range of $51-82 \%$. Considering, effluent of SBR system at HRT 24 hours with the Readily biodegradable, the value percentage increase of $62.00 \%$, $57.79 \%, 60.54 \%, 54.53 \%, 41.79 \%$ and $36.03 \%$, respectively, and Slowly biodegradable hydrolysis into Readily biodegradable was to increases.
\end{abstract}

Index Terms-Oily wastewater, COD fractionations, sequencing batch reactor (SBR).

\section{INTRODUCTION}

Wastewater from gas stations has become a major cause of environmental pollution in urban areas. Each gas station generates an average of $20 \mathrm{~m}^{3}$ wastewater per day. Carwash operation utilizing approximately 300-600 L of water per car is a primary contributor of wastewater, which mainly consists of toxic substances such as phenols, petroleum hydrocarbons, and polyaromatic hydrocarbons. Those substances are inhibitory to plant and animal growth, as well as mutagenic and carcinogenic to human being [1]. The oil compounds in the carwash wastewater are mainly present as an oil water emulsion with the presence of emulsifier. Conventional treatment systems for oily wastewater from gas stations are parallel or corrugated plate interceptors (PPI or CPI) designed to treat only free oil and settled solid. Therefore, those treatment systems have little effect on the oil water emulsion containing about $50-100 \mathrm{mg} / \mathrm{l}$ of oil. Consequently, wastewater discharged from gas stations hardly meets the effluent standards of $15 \mathrm{mg} / \mathrm{l}$ and $120 \mathrm{mg} / \mathrm{l}$ for oil and chemical oxygen demand (COD), respectively.

Physical treatments of oily wastewater such as API gravity separator, dissolved air floatation (DAF), and ultrafiltration cannot remove the pollutants completely but just transfer to a

Manuscript received May 12, 2018; revised June 29, 2018.

The authors are with School of Environmental Engineering, Institute of Engineering, Suranaree University of Technology, Nakhon Ratchasima, 30000, Thailand (e-mail: boonchai@sut.ac.th, w_watcharapol@hotmail.com). more concentrated waste [2]. The chemical coagulation process that usually precedes with the biological process is replaced with a more advanced process such as electrocoagulation [3]. However, the physical treatment methods are also unable to remove soluble fraction of the wastewater and these processes pose high costs and have fairly low application on an industrial scale [4].

Moreover, the conventional biological treatment techniques are mostly incapable of producing a complete elimination of hydrocarbon in the stable emulsion. Low removal efficiency of the conventional biological processes is probably due to the inhibitive effects of toxic substances and hydrophobic characteristics of oil components [2]. Therefore, it is necessary to investigate the concentration threshold of oil introduced into a biological treatment system to prevent the occurrence of a shock load in the system that adversely affects the treatment efficiency.

\section{MATERIALS AND METHOD}

\section{A. Synthesis of Oily Wastewater}

Synthetic oily wastewater was prepared in accordance with the survey data from various gas stations in Thailand [5]. It showed that O\&G concentration and BOD of carwash wastewater were in the range of $7.8-280.5 \mathrm{mg} / \mathrm{L}$ and $10-$ $1220 \mathrm{mg} / \mathrm{L}$, respectively. The oil concentration in this study was varied from $50-500 \mathrm{mg} / \mathrm{L}$. Glucose was supplemented into the feed wastewater to simulate the carbon source. The components of the synthetic oily wastewater contained glucose $98.74 \mathrm{mg} / \mathrm{L}, \mathrm{K}_{2} \mathrm{HPO}_{4} 880 \mathrm{mg} / \mathrm{L}, \mathrm{KH}_{2} \mathrm{PO}_{4} 440 \mathrm{mg} / \mathrm{L}$, $\mathrm{NH}_{4} \mathrm{Cl} 105 \mathrm{mg} / \mathrm{L}, \mathrm{MgSO}_{4} 7 \mathrm{H}_{2} \mathrm{O} 150 \mathrm{mg} / \mathrm{L}, \mathrm{ZnSO}_{4} 7 \mathrm{H}_{2} \mathrm{O} 5$ $\mathrm{mg} / \mathrm{L}, \mathrm{FeSO}_{4} 5 \mathrm{mg} / \mathrm{L}, \mathrm{MnSO}_{4} 5 \mathrm{mg} / \mathrm{L}, \mathrm{CaCl}_{2} 20 \mathrm{mg} / \mathrm{L}, \mathrm{CuSO}_{4}$ $0.02 \mathrm{mg} / \mathrm{L}, \mathrm{CoCl}_{2} 0.02 \mathrm{mg} / \mathrm{L}$, and emulsifier $13.6 \mathrm{mg} / \mathrm{L}$. Commercial lubricant PTT Max Speed 4T, manufactured by Petroleum Authority of Thailand (PTT), was used in this study.

\section{B. Experimental Setup}

The experiments were operated with the sequencing batch reactor (SBR) mode. Each cycle went through four main steps: filling, reacting (aeration), settling and drawing. Three liter-glass-bottles were used as model reactors. The concentrations of lubricant oil were varied for $50,75,100$, 150,300 , and $500 \mathrm{mg} / \mathrm{L}$ in six reactors with the control HRT of 24 hrs. The reactors were mixed and aerated by the compressed air through stone air diffusers to maintain a suitable mixing condition and to supply sufficient dissolved oxygen for microorganism growth ( $\mathrm{DO}=2-4 \mathrm{mg} / \mathrm{L})$. The $\mathrm{pH}$ of the reactors was controlled within the range of 6.2-8.0 by adding $\mathrm{NaOH}$. The reactors were operated without sludge 
wastage except for a sampling purpose.

\section{Biodegradability Kinetic Evaluations}

The OUR experiments were conducted to determine the biodegradability kinetic coefficients of the aerobic heterotrophs via the procedure of [6]. The batch tests shown in Fig. 1 were maintained at the temperature $30 \pm 0.5{ }^{\circ} \mathrm{C}$ and $\mathrm{pH} \quad 7 \pm 0.2$ with suppressing nitrification of $70 \mathrm{mg}$ $\mathrm{N}$-ammonia/L. The sludge samples were obtained from a municipal activated sludge process. The initial mixed liquor volatile suspended solids (MLVSS) concentration $\left(\mathrm{X}_{0}\right)$ in the sludge samples was about $485 \mathrm{mg} / \mathrm{L}$ for the batch tests and the various lubricant oil initial substrate concentrations $\left(S_{0}\right)$ that govern the quality of the batch respirometric tests. The OUR results were used for calculating the maximum specific growth rates $\left(\mu_{\max }\right)$, substrate utilization rate $\left(r_{x}\right)$, half-velocity constant $\left(\mathrm{K}_{\mathrm{S}}\right)$, and sludge yield coefficient $(\mathrm{Y})$ based on Monod kinetics by regression analysis.

\section{Sampling and Analytical Methods}

The influent and effluent samples of the SBR were analyzed following the standard methods for the examination of water and wastewater [7] for COD, total Kjeldahl nitrogen, and O\&G. Biochemical oxygen demand (BOD) was determined with an OxiTop®-C measuring pressure head instrument (Expotech USA Inc., Houston, TX, USA). The carbonaceous materials were measured in terms of the COD parameters subdivided into a number of fractions following [8].

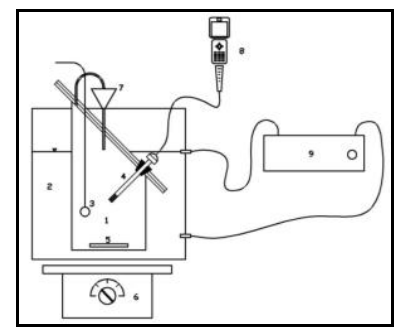

Fig. 1. Respirometer: 1) Respiration cell, 2) Water jacket, 3) Air diffuser, 4) DO probe, 5) Magnetic bar, 6) Magnetic stirrer, 7) Expansion funnel, 8) DO meter, and 9) Water bath.

\section{RESULTS AND DISCUSSION}

\section{A. Removal Efficiencies of $C O D$ and $O \& G$}

Table I and Fig. 2 summarize the variation in the COD and $\mathrm{O} \& \mathrm{G}$ concentrations of the influent and effluent throughout the experimental runs. The results showed that the effective removal of COD was in the range of $84-87 \%$, which is insignificant difference when increasing in the oil concentrations up to $500 \mathrm{mg} / \mathrm{L}$, as shown in Fig. 1. The COD effluent concentrations were $30.0 \pm 7.7,35.3 \pm 8.6,40.8 \pm 10$, $50.8 \pm 9.0,80.4 \pm 9.7$ and $121 \pm 4.5 \mathrm{mg} / \mathrm{L}$ for the lubricant oil concentrations of $50,75,100,150,300$, and $500 \mathrm{mg} / \mathrm{L}$, respectively. All COD effluents are all lower than the standard of COD effluent $(200 \mathrm{mg} / \mathrm{L})$ recommended by the Ministry of Science, Technology and Environment in Thailand for a gas station. Considering the oil treatment, the removal efficiencies for the investigated concentrations were found to be in the range of $51-82 \%$.

TABLE I: WATER QUALITY AND EFFICIENCY OF LUBRICANT OIL TREATED BY SBR

\begin{tabular}{|c|c|c|c|c|c|c|c|}
\hline & \multirow{2}{*}{ Parameter } & \multicolumn{6}{|c|}{ Concentration of lubricant oil (mg/L) } \\
\hline & & 50 & 75 & 100 & 150 & 300 & 500 \\
\hline \multirow{3}{*}{ COD } & inlet (mg/L) & $193 \pm 3.3$ & $243 \pm 3.4$ & $277 \pm 3.6$ & $361 \pm 4.1$ & $611 \pm 6.8$ & $946 \pm 11$ \\
\hline & Outlet (mg/L) & $30.0 \pm 7.7$ & $35.3 \pm 8.6$ & $40.8 \pm 10$ & $50.8 \pm 9.0$ & $80.4 \pm 9.7$ & $121 \pm 4.5$ \\
\hline & Efficiency $(\%)$ & 84.78 & 85.48 & 85.11 & 85.99 & 87.07 & 87.34 \\
\hline \multirow{3}{*}{ O\&G } & inlet $(\mathrm{mg} / \mathrm{L})$ & $155 \pm 11$ & $173 \pm 7$ & $203 \pm 12$ & $261 \pm 7$ & $396 \pm 4$ & $537 \pm 6$ \\
\hline & Outlet (mg/L) & $59 \pm 1$ & $74 \pm 6$ & $86 \pm 2$ & $119 \pm 6$ & $165 \pm 18$ & $184 \pm 4$ \\
\hline & Efficiency $(\%)$ & 61.9 & 57.2 & 57.6 & 54.4 & 58.3 & 65.7 \\
\hline \multirow{3}{*}{ TKN } & inlet $(\mathrm{mg} / \mathrm{L})$ & $14.6 \pm 1.0$ & $16.3 \pm 0.3$ & $16.3 \pm 0.3$ & $17.4 \pm 1.7$ & $17.5 \pm 0.9$ & $17.6 \pm 0.9$ \\
\hline & Outlet (mg/L) & $5.3 \pm 0.97$ & $5.9 \pm 0.28$ & $5.3 \pm 0.97$ & $5.2 \pm 0.32$ & $5.7 \pm 0.70$ & $3.7 \pm 0.16$ \\
\hline & Efficiency (\%) & 63.7 & 63.8 & 67.5 & 70.1 & 67.4 & 79 \\
\hline \multirow{3}{*}{ BOD } & inlet $(\mathrm{mg} / \mathrm{L})$ & 55.40 & 61.60 & 71.90 & 88.80 & 152.00 & 248.00 \\
\hline & Outlet (mg/L) & 18.60 & 20.40 & 24.70 & 27.70 & 33.60 & 43.60 \\
\hline & Efficiency (\%) & 66.43 & 66.88 & 65.65 & 68.81 & 77.89 & 82.42 \\
\hline
\end{tabular}

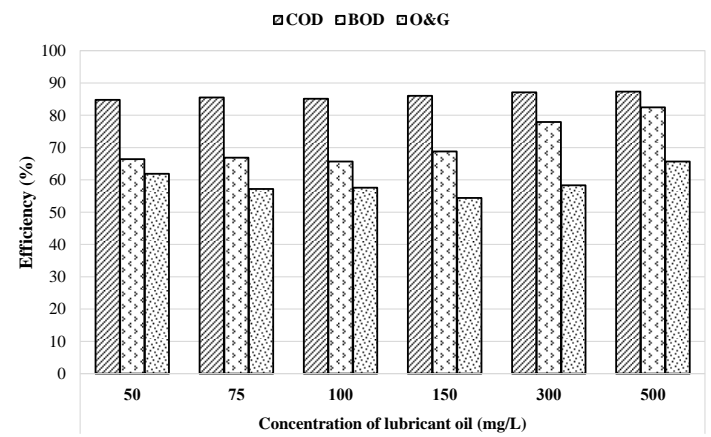

Fig. 2. Organic and O\&G removal of various lubricant oil treated by SBR.

\section{B. Biodegradability and COD Fractionations}

Potential biodegradability was evaluated with the results illustrated in Fig 3. The BOD/COD ratio of oily wastewater was very low, which was in the range of $0.25-.029$ for the investigated oil concentrations of $50-500 \mathrm{mg} / \mathrm{L}$. The ratio of $\mathrm{BOD} / \mathrm{COD}$ is often used as an index to evaluate a biodegradability of wastewater. BOD/COD > 0.45 indicates that the biodegradability is very good; for $\mathrm{BOD} / \mathrm{COD}=0.45$, the biodegradability is good; for $\mathrm{BOD} / \mathrm{COD}=0.2-0.3$, the biodegradability is poor; for $\mathrm{BOD} / \mathrm{COD}<0.2$, the biological 
treatment is unsuitable [9]. After treated by the SBR system, the $\mathrm{BOD} / \mathrm{COD}$ ratio was increased to be in the range of $0.36-0.62$. The $50 \mathrm{mg} / \mathrm{L}$ oil concentration provided the highest ratio.

The COD fractionations were evaluated and the results are illustrated in Fig 4 and 5. It showed that the slowly biodegradable organic matter was hydrolyzed to readily biodegradable organic matter and inert soluble organic matter. Readily biodegradable organic substrate $\left(S_{S}\right)$ increased, and the hydrolysis from $X_{S}$ into $S_{S}$ and $S_{I}$ after treated by the SBR was observed. Considering the effluent of SBR system at HRT 24 hours, the Readily biodegradable (Ss) increased in percentage of about $60 \%, 58 \%, 60 \%, 55 \%, 42 \%$ and $36 \%$ for the oil concentrations of $50 \mathrm{mg} / \mathrm{L}, 75 \mathrm{mg} / \mathrm{L}, 100 \mathrm{mg} / \mathrm{L}$, $150 \mathrm{mg} / \mathrm{L}, 300 \mathrm{mg} / \mathrm{L}$ and $500 \mathrm{mg} / \mathrm{L}$, respectively. Plus, an increase of slowly biodegradable hydrolysis into readily biodegradable was observed.

$\mathrm{X}_{\mathrm{I}}$, calculated from the difference between the soluble COD fraction (CODsol) and $\mathrm{X}_{\mathrm{S}}$, was about $428 \mathrm{mg} / \mathrm{L}$ or
$50.05 \%$ of the total COD in case of the $500 \mathrm{mg} / \mathrm{L}$ oil influent, and was found to decrease to about $36.25 \mathrm{mg} / \mathrm{L}$ or $29.96 \%$ of the total COD after treating by SBR. The $\mathrm{X}_{\mathrm{I}}$ fraction (inert particulates) exits the plant and bounds up in sludge flocs [10]. Although the XI fraction is inert, it can be removed by a biological treatment [11].

\section{Effect of $S_{0} / X_{0}$ Ratio on the Biodegradation}

The ratio of initial substrate concentration $\left(S_{0}\right)$ to initial biomass concentration $\left(\mathrm{X}_{0}\right)$ indicates the availability of a carbon source and inhibition for microbial growth. The oily wastewater showed a significant inhibitory effect on decreasing the specific growth rate of microorganisms at a higher concentration (Fig. 6) [12]. The sole carbon source for maximum specific growth rate was found to be with a maximum $\mathrm{S}_{0} / \mathrm{X}_{0}$ ratio 0.020-0.389.

TABLE II: BIOKINETIC EXPERIMENTAL DATA OF OILY WASTEWATER INFLUENT

\begin{tabular}{|c|c|c|c|c|c|c|}
\hline $\begin{array}{c}\mathrm{S} \\
\mathrm{mg} / \mathrm{l}\end{array}$ & F/M & $\begin{array}{c}\mathbf{r}_{\mathrm{x}} \\
\mathrm{mg} \mathrm{COD/mg} \mathrm{MLVSS}\end{array}$ & $\begin{array}{c}\mathrm{Y} \\
\mathrm{mg} \mathrm{MLVSS} / \mathrm{mg} \text { COD }\end{array}$ & $\begin{array}{c}\mu \\
d^{-1}\end{array}$ & $\begin{array}{c}\mu_{\max } \\
\mathbf{d}^{-1}\end{array}$ & $\begin{array}{c}\mathrm{K}_{\mathrm{s}} \\
\mathrm{mg} \mathrm{COD/l}\end{array}$ \\
\hline 9.3750 & 0.0200 & 0.0426 & 0.1692 & 0.1730 & \multirow{9}{*}{5.2264} & \multirow{9}{*}{40.6700} \\
\hline 10.5000 & 0.0216 & 0.0553 & 0.2829 & 0.3752 & & \\
\hline 11.6250 & 0.0239 & 0.0554 & 0.4421 & 0.5874 & & \\
\hline 20.6250 & 0.0424 & 0.0937 & 0.4521 & 1.0172 & & \\
\hline 31.8750 & 0.0655 & 0.1594 & 0.5121 & 1.9589 & & \\
\hline 43.1250 & 0.0887 & 0.2156 & 0.5680 & 2.9393 & & \\
\hline 96.4554 & 0.1983 & 0.3445 & 0.6034 & 4.9883 & & \\
\hline 99.6528 & 0.2049 & 0.3322 & 0.6165 & 4.9152 & & \\
\hline 189.3750 & 0.3893 & 0.2594 & 0.6296 & 3.9197 & & \\
\hline
\end{tabular}

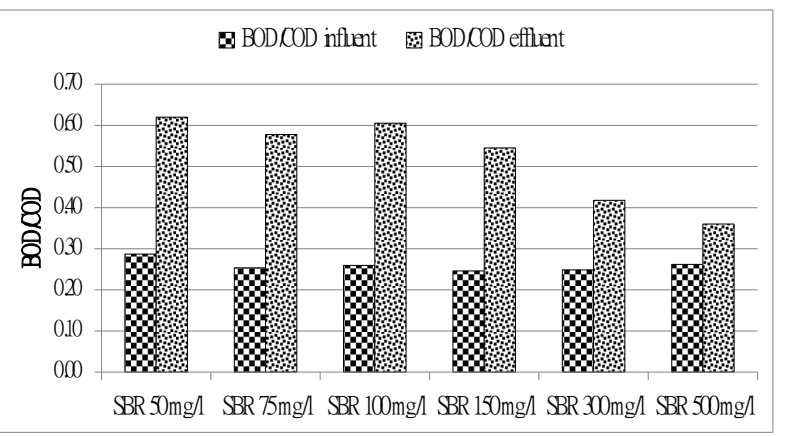

Fig. 3. BOD/COD of influent and effluent oily wastewater.

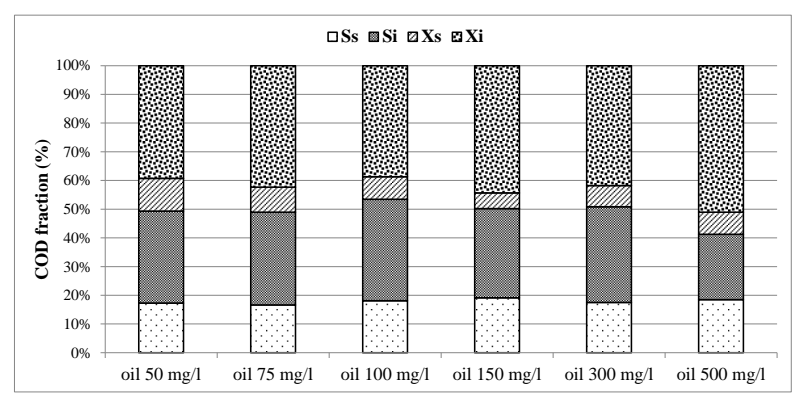

Fig. 4. COD fractionations on influent oily wastewater.

Values of biokinetic coefficients of oily wastewater treated by SBR shown in Table II indicated that substrate utilization rate $\left(r_{x}\right)$ and maximum specific growth rate $\left(\mu_{\max }\right)$ were increased when substrate concentration increased, which explained the highest organic removal in SBR.
Results of biokinetics experiments show that a SBR have the higher potential for organic removal of oily wastewater. Moreover, it can also be observed that the yield (Y) of the bacterial culture is high. This indicates that high excess sludge would be produced from the bacterial system.

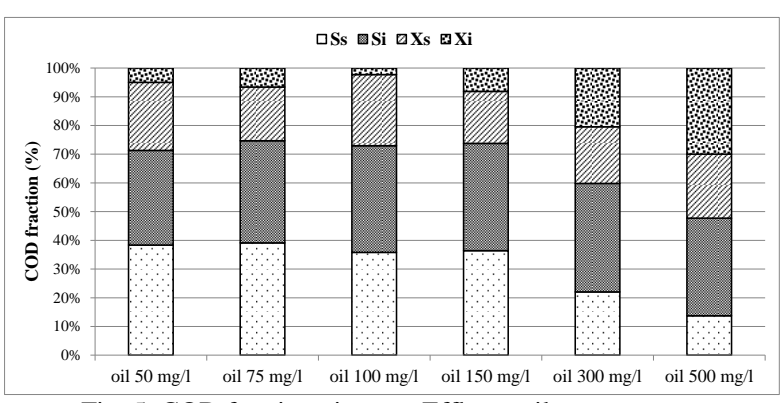

Fig. 5. COD fractionations on Effluent oily wastewater.

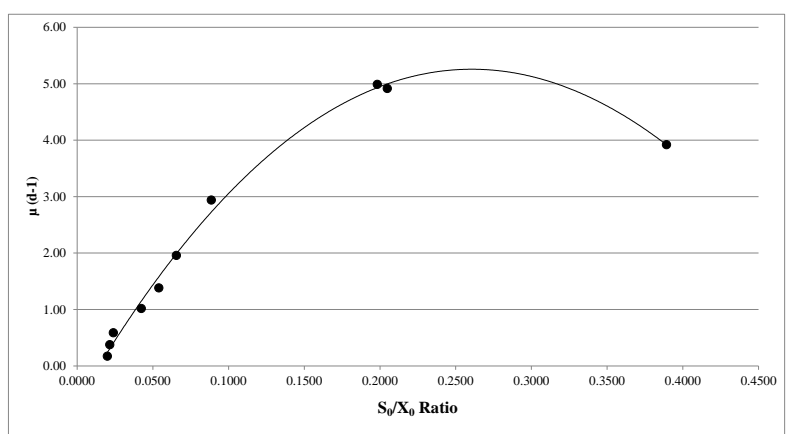

Fig. 6. Relation between $\mu$ and S0/X0 ratio. 


\section{CONCLUSIONS}

The results indicated that the effective removal of COD was in the range of $84-87 \%$. The oil removal efficiency was found to be in the range of $51-82 \%$. Considering the effluent of SBR system at HRT 24 hours, the Readily biodegradable $\left(\mathrm{S}_{\mathrm{s}}\right)$ increased in percentage of about $60 \%, 58 \%, 60 \%, 55 \%$, $42 \%$ and $36 \%$ for the oil concentrations of $50 \mathrm{mg} / \mathrm{L}, 75 \mathrm{mg} / \mathrm{L}$, $100 \mathrm{mg} / \mathrm{L}, 150 \mathrm{mg} / \mathrm{L}, 300 \mathrm{mg} / \mathrm{L}$ and $500 \mathrm{mg} / \mathrm{L}$, respectively. Plus, an increase of slowly biodegradable hydrolysis into readily biodegradable was observed.

\section{ACKNOWLEDGEMENTS}

This study was supported by Suranaree University of Technology and Thailand Institute of Scientific and Technological Research

\section{REFERENCES}

[1] A. F. Viero, T. M. Melo, A. P. R. Torres, N. R. Ferreira, G., L. Sant, P. V. Borges, and M. J. Santiago, "The effects of long-term feeding of high organic loading in a submerged membrane bioreactor treating oil refinery wastewater," Journal of Membrane Science, vol. 319, pp. 223-230, 2008.

[2] W. Scholz and W. Fuchs, "Treatment of oil contaminated wastewater in a membrane bioreactor," Water Res, vol, 34, no. 14, pp. 3621-3629, 2000.

[3] L. S. Perez, O. M. Rodriguez, S. Reyna, J. L. Sánchez-Salas, J. D. Lozada, M. A. Quiroz, and E. R. Bandala, "Oil refinery wastewater treatment using coupled electrocoagulation and fixed film biological processes," Phys. Chem., vol. 91, pp. 53-60, 2016.

[4] P. Seyedramin, Z. Nasim, and B. Babak, "Considering membrane sequencing batch reactors for the biological treatment of petroleum refinery wastewaters," Journal of Membrane Science, vol. 523, pp. 542-550, 2017.

[5] P. T. Tri, "Oily wastewater treatment by membrane bioreactorprocess coupled with biological activated carbon process," Master's thesis, Resources and Development Thailand, Asian Institute of Technology School of Environment, 2002.
[6] G. A. Ekama, P. L. Dold, and G. V. R. Marais, "Procedures for determining influent COD fractions and the maximum specific growth rate of heterotrophs in activated sludge systems," Water Sci. Technol., vol. 18, pp. 91-114, 1986.

[7] Standard Methods for the Examination of the Water and Wastewater, American Public Health Association/American Water Works Association/Water Environment Federation, Washington DC, USA.

[8] M. C. Wentzel, A. Mbewe, M. T. Lakay, and G. A. Ekama, "Batch test for characterization of the carbonaceous materials in municipal wastewaters," Water SA, vol. 25, no. 3, pp. 327-336, 1999.

[9] P. Racho, "Investigation of downflow hanging sponge (DHS) system using bacterial and fungal cultures as a post treatment for the UASB effluent of a tapioca starch wastewater," Ph.D. thesis, Suranaree University of Technology. Nakhonratchasima, Thailand, 2009.

[10] M. Henzs, P. Harremoes, J. Jansen, and E. Arvin, Wastewater Treatment Biological and Chemical Process, New York, 2002.

[11] C. Fall, E. Millán-Lagunas, K. M. Bâ, I. Gallego-Alarcón, D. García-Pulido, C. Díaz-Delgado, and C. Solís-Morelos, "COD fractionation and biological treatability of mixed industrial wastewaters," Journal of Environmental Management, vol. 113, pp. 71-77, 2012.

[12] B. Wimonmas, W. Boonchai, and R. Patcharin, "Azo dye reduction and biodegradability mechanisms during an anaerobic process," Suranaree J. Sci. Technol., vol. 20, no. 1, pp. 1-9. 2013.

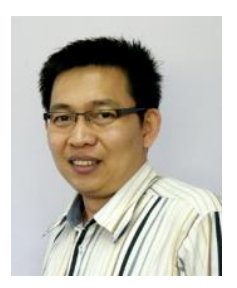

Boonchai Wichitsathian is Asst. Prof. in Asian Institute of Technology, Thailand, 2004. Present he is lecturer, School of Environmental Engineering, Suranaree University of Technology, Nakhon Ratchasima, Thailand.

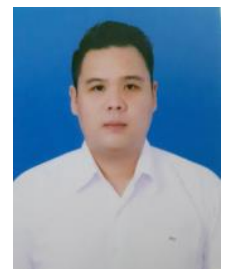

W. Wonglertarak received the bachelor's degree in environmental engineering, the master degree in environmental engineering at Suranaree University of Technology, Nakhon Ratchasima, Thailand. And now is a graduate student in environmental engineering of Suranaree University of Technology, NakhonRatchasima, Thailand. His researches interested are in biological wastewater treatment. 